\title{
Kebebasan Beragama Gereja Yesus Kristus dari Orang-orang Suci Zaman Akhir di Ngagel Surabaya Perspektif Joseph Raz
}

\author{
Amonda Siti Faridah, Riska Fitriani, Mufidatul Fitriyah, Umi Salamah Wijayanti, Dinda \\ Indahsyah, Karima Nur Chayati, Kasiyono, Ali Mas’ud, Roqib Yanuarinda P, Ade Oies \\ Hasbiansyah, M Rizky Pratama
}

\begin{abstract}
Abstrak;
Selaras dengan teori kebebasan yang coba disampaikan Joseph Raz, dimana kebebasan beragama sesungguhnya adalah kombinasi dari dua hal, yakni kebebasan positive dan negative. Kebebasan negative, yakni kebebasan pada manusia yang menuntut tidak adanya campur tangan orang lain. Artinya, seseorang dapat bebas ketika orang lain tidak ikut campur tangan terhadap tindakan dan keputusannya. Sementara dalam hal pemenuhan kebebasan positive, yakni berupa perlindungan ketika beribadah, pemenuhan subsidi, pengadaan alat peribadatan, sampai kekhusyukan, maka sudah seharusnya pemerintah memberikan kebebasan tersebut kepada setiap masyarakatnya yang beragama apapun itu. Masyarakat sendiri, juga perlu bersikap adil, dan mulai memandang perbedaan itu indah. Mereka juga harus belajar dan mulai mengerti bahaya dari hate speech yang dilontarkan secara sengaja kepada kelompok agama atau kepercayaan lain. Dalam kubu Kristen sendiri, masyarakat perlu mengakui "sesama Kristen" adalah juga sudah seharusnya ditanamkan, mengingat Kristen dalam gereja Mormon ini adalah minoritas ditengah-tengah minoritas. Sehingga, dapat telaksana kebebasan yang sesungguhnya, dan kedamaian.
\end{abstract}

Keywords: Josep Raz, Gereja.

\section{A. Pendahuluan}

Gereja Yesus Kristus dari Orang-orang Suci Zaman Akhir adalah salah satu gereja yang hidup dan berkembang di Indonesia. Dia adalah gereja yang lahir di Amerika, yang kemudian dibawa oleh para missionaries untuk disebarkan. Situasi keagamaan di Amerika pada awal abad ke-19 mempersiapkan iklim yang kondusif bagi perkembangan gerakan-gerakan keagamaan baru. Gereja-gereja utama (antara lain Episcopal, Metodis, Baptis, Presbyterian, dan Kongregasionalis) secara umum lemah, sedangkan kemajemukan dan kebebasan beragama yang dijamin undang-undang merangsang pengungkapan rasa keagamaan yang bersifat individual dan independen. Demokratisasi kebudayaan Amerika, kebangunan besar kedua dan kebangunan rohani yang merupakan lanjutannya, ikut merangsang dan meningkatkan individualism religious ini. Ditambah dengan berbagai pertikaian dan kekhawatiran disepanjang tahun 1830-an, maka lahirlah gerakan-gerakan baru, terutama dari gereja-gereja Protestan. Salah satu 
diantaranya adalah Gereja Yesus Kristus dari Orang-orang Suci Zaman Akhir (OSZA) atau The Church of Jesus Christ of Latter Day Saints. Orang-orang di luar gereja ini mengenalnya dengan Gereja Mormon. ${ }^{1}$

Berbeda dengan kebanyakan gereja pada umumnya di Indonesia, gereja ini meyakini bahwa mereka adalah gereja yang didirikan oleh seorang nabi, pelihat dan pewahyu yaitu Joseph Smith di Utara New York pada tahun 1830, disamping mereka juga percaya akan Yesus Kristus sebagai juru selamat. Joseph Smith dipanggil untuk memulihkan Injil. Ia membuktikan kelayakannya, diberi misi khusus sebagai seorang nabi Allah. Melalui ia, Tuhan melaksanakan suatu pekerjaan yang besar dan menakjubkan dengan menampilkan Kitab Mormon, memulihkan imamat, menyatakan kebenaran-kebenaran Injil yang berharga, mengorganisasi Gereja Yesus Kristus, serta menetapkan pekerjaan Bait Suci. ${ }^{2}$

Di Indonesia, Mormon memanglah bukan satu-satunya gereja dengan keunikan, yang membuatnya berbeda dari kebanyakan gereja secara mayoritas. Akan tetapi, perbedaan tersebut tidak sepantasnya menjadikannya sebagai kelompok keagamaan yang terpinggirkan, dan tidak terpenuhi kebebasannya. Terbukti, gereja yang beroperasi sejak lebih dari 16 tahun yang lalu ini, ${ }^{3}$ mendapatkan hak-haknya terkhusus kebebasannya mendirikan rumah ibadah, dan pemenuhan Negara atas keperluan peribadatan mereka. Rumah ibadah yang telah berdiri megah ini salah satunya terletak di Surabaya Jawa Timur, tepatnya di Jl. Upa Jiwa No. 23, Ngagel, Wonokromo. Dalam pendiriannya, rumah ibadah tersebut tidak memiliki kendala yang berarti. Kebanyakan masalah yang ada di Indonesia terkait agama adalah pendirian rumah ibadah. Banyak persyaratan yang dibebankan Negara kepada kelompok keagamaan dalam hal kelegalan. Namun, hal tersebut tidak menjadi masalah bagi gereja Mormon. Mereka sama sekali tidak mendapati perlakuan diskriminasi mengingat keunikan dari gereja ini sendiri. Negara tetap memberikan kebebasan dan hak agar jemaat dapat melakukan peribadatan bersama. Hal ini menjadi keunikan tersendiri mengingat Indonesia adalah Negara yang mengatur secara ketat perihal agama-agama yang diizinkan ada dan berkembang di dalamnya.

1 Nurdewi Mayangsari, Konsep Kenabian dalam Doktrin Kristen Mormon Skripsi.pdf, diakses melalui http://repository.uinjkt.ac.id/dspace/bitstream/123456789/36629/2/NURDEWI\%20MAYANG\%20SARI-FU.pdf.

Pada 4 Juli 2018, 3,4

${ }^{2}$ Ibid.

${ }^{3}$ Christin Prayitno Silalahi, Wawancara, Surabaya, 1 Juli 2018. 
Selain itu, dalam keamanan dan pemenuhan keperluan peribadatan, Negara juga memberikannya tanpa diskriminasi. ${ }^{4}$

Selaras dengan perlakuan Negera, perlakuan masyarakat sekitar juga semakin tahun semakin membaik dalam merespon perbedaan yang ada dalam gereja ini, terlebih dari kubu keKristenan sendiri. Gereja Mormon di Surabaya sejauh ini belum pernah mengalami perlakuan atau tindak kekerasan dari masyarakat sekitar.

\section{B. Metode Penelitian}

\section{Jenis Penelitian}

Jenis penelitan yang digunakan adalah penelitian lapangan (field research) yang bersifat kualitatif. Pada dasarnya penelitian ini merupakan kegiatan deskriptif analisis, sebagai upaya memberikan penjelasan dan gambaran secara komperhensif tentang Kebebasan Beragama dan Pendirian Rumah Ibadah di Gereja Yesus Kristus dari Orangorang Suci Zaman Akhir, Jl. Upa Jiwa No. 23, Ngagel, Wonokromo, Surabaya.

\section{Sumber Data}

Sumber data yang digunakan dalam penelitian ini adalah sebagai berikut:

\section{a. Sumber Data Primer}

Data hasil wawancara, wawancara ini bertujuan untuk mengetahui informasi dengan menyelidiki informasi yang lalu dan sekarang oleh para partisipan untuk mengetahui pemikiran dan presepsi mereka. Metode wawancara dipilih untuk menunjang peneliti dalam memperoleh data seperti tanggapan dari masing-masing district president, missioner dan para public affair.

Data observasi, mengamati secara langsung suatu kegiatan yang diteliti. Dalam observasi ini diusahakan mengamati keadaan yang wajar dan yang sebenarnya seperti kegiatan yang dilakukan oleh district president, missioner, para public affair, dan jemaat dalam peribadatannya. Pengamatan tersebut diperoleh dari penggabungan dari kenyataan yang terlihat, mendengar, bertanya sehingga pengamatan bisa terarah secara sistematis.

${ }^{4}$ Ibid. 


\section{b. Sumber Data Sekunder}

Data sekunder diperoleh dari data-data resmi yang tersedia hasil, data ini sangat berhubungan untuk setiap topik penelitian ini. Pengumpulan data-data berupa bahanbahan tertulis dari jurnal, buku, dan hasil karya pnelitian yang berhubungan dengan kebebasan beragama.

\section{Teknik Pengumpulan Data}

\section{a. Observasi}

Metode observasi ini dilakukan untuk memperoleh informasi tentang kelakuan manusia seperti terjadi dalam kenyataannya. Dengan observasi dapat diperoleh gambaran yang lebih jelas tentang kehidupan sosial, observasi juga dilakukan apabila belum banyak keterangan dimiliki tentang masalah yang diselidiki. Dalam observasi ini diusahakan mengamati keadaan yang wajar dan yang sebenarnya tanpa usaha yang disengaja untuk mempengaruhi, mengatur atau memanipulasikannya. ${ }^{5}$ Dalam hal ini peneliti akan mengetahui keadaan kebebasan pengurus gereja dan jemaat gereja Kristen dari Orangorang Suci Zaman Akhir dalam mengorganisir gereja dan melaksanakan peribadatannya.

\section{b. Wawancara}

Wawancara adalah suatu cara mengumpulkan data atau informasi dengan cara langsung bertatap muka dengan informan agar mendapatkan data lengkap dan mendalam ${ }^{6}$. Pengambilan data dengan metode ini dilalui dengan proses Tanya jawab, yang dilakukan secara sistematis dan berdasarkan pada tujuan penelitian. Metode ini dilakukan dengan cara dialog tanya jawab kepada informan yang telah mengalami pemilihan terlebih dahulu. ${ }^{7}$ Maka peneliti akan mengadakan wawancara secara langsung dengan pihak gereja terkait. Metode ini dilakukan untuk analisis data secara langsung agar mendapatkan bukti secara langsung kebenarannya.

\section{Kerangka Teori}

\footnotetext{
${ }^{5}$ S.Nasution, Metode Research, (Jakarta: PT. Bumi Aksara 2009), 106.

${ }^{6}$ M Thoriqul Huda, "Potret Kerukunan Pemuda Lintas Agama Di Jawa Timur," in PROCEEDINGS: Annual Conference for Muslim Scholars, 2018, 929-36.

${ }^{7}$ James P. Spraddly, Etnografi, (Yogyakarta: Tiara Wacana, 2006), 76,
} 
Sebelum membahas mengenai kebebasan dalam pandangan Raz, terdapat latarbelakang mengapa Ia berusaha untuk menjelasakan konsep kebebasan. Sebelumnya, Raz tertarik tentang keanekaragaman moral,tanpa mengesampingkan keanekaragaman etnis, kultur bahkan politik pengakuan dan perbedaan, ia mencoba memberikan pandangan bagaimana implikasi keanekaragaman moral yang ada. Moral direfleksikan dalam kesejahteraan manusia. Mengadopsi pemikiran Aristoteles bahwa kesejahteraan manusia dapat terwujud apabila sesorang dapat memberikan inspirasi dan bermanfaat bagi orang lain sepanjang hidupnya. Terkadang, kalau berbicara kesejahteraan manusia adalah definisi yang penuh harapan utopis semata. Meskipun demikian, pernyataan tersebut dapat diupayakan dan diaktualisasikan kembali kepada sturktur sosial yang berkaitan dengan fungsi individu dan kelompok dalam masyarakat. Kemudian, karena adanya kemajemukan yang ada dalam masyarakat tentu saja akan memengaruhi corak kesejahteraan yang mereka inginkan. Hal tersebut menyebabkan munculnya pilihanpilihan yang harus dipilih demi kesejahteraan bersama. Itu sudah menjadi konsekwensi logis bagi semua komponen masyarakat. ${ }^{8}$

Selanjutnya, mengacu pada keadaan masyarakat Barat modern, Raz mengatakan bahwa otonomi juga merupakan komponen universal dari kesejahteraan manusia. Otonomi merupakan proses penciptaan diri terus-menerus melalui keputusan-keputusan kecil dan besar pada wilayah penting dari kehidupan seseorang. Otonomi dapat berlaku apabila telah memenuhi syarat; Pertama, pilihan harus bebas dalam arti tidak dipaksa dan tidak dimanipulasi. Kedua, pilihan harus terencana dan harus berdasarkan penilain yang hati-hati. Ketiga, berhubungan dengan hal-hal penting. Keempat, pilihan harus asli dalam pengertian dibuat antara opsi-opsi penting yang berbeda dan yang sama-sama bernilai. Pemikiran Raz pada masalah otonomi terbagi menjadi dua bagian. Pertama, otonomi adalah pokok pada pemahaman diri dunia Barat dan suatu nilai intrinsik bagi masyarakat Barat. Bukan suatu nilai intrinsik atau secara universal, namun hanya bagi masyarakat Barat disebabkan cara mereka hingga terbentuk secara historis. Kedua, otonomi diperlukan agar berhasil dalam masyarakat modern, dan juga mempunyai nilai instrumental. Mengenai argumen yang pertama, mungkin banyak orang di Barat benarbenar menghargai otonomi, tetapi beberapa lainnya tidak, sebagaimana terbukti dalam

${ }^{8}$ Bhikhu Parekh, Rethinking multicuturalism, (Yogyakarta: Kansius, 2008), 127 
dukungan rakyat gerakan-gerakan fasis dan gerakan sayap kanan, kolektivisme, fundamentalisme keagamaan, dan cara-cara pemujaan keagamaan yang aneh. Argumen Raz juga tidak lebih baik dari yang sebelumnya. Ia melihat otonomi sebagai sebuah syarat fungsional masyarakat modern, tidak berbeda dari macam-macam keterampilan yang secara sosial diperlukan dan tidak menyangkut masalah moral seperti keterampilan literasi dan numerasi, dan tidak dapat memberikan status satu nilai moral pada otonomi sebagaimana Raz sangat ingin memberikannya. Raz menganggap bahwa otonomi adalah hal yang pokok bagi masyarakat modern, ia mempertanyakan apa yang harus dilakukan dengan kelompok-kelompok seperti kelompok imigran, masyarakat pribumi dan komunitas keagamaan yang tidak terlalu menghargai hal itu. Karena Raz hanya menunjukkan bahwa otonomi merupakan satu nilai yang dipuja sangat dalam oleh Barat dan tidak universal, penilaiannya berdasar pada satu preferensi kultural dan tidak dapat mengklaim kebenaran yang lebih luas. ${ }^{9}$

Otonom kebebasan ini memiliki tiga ciri yaitu Pertama, fokus utamanya yaitu melindungi kebebasan yang bernilai positif sehingga dipahami sebagai kapasitas untuk otonom yang didalamnya terdiri dari kesediaan beberapa pilihan dan kemampuan yang dibutuhkan untuk kehidupan yang otonom. Manusia dengan beberapa pilihannya mampu memutuskan yang terbaik bagi dirinya dan untuk masa depannya. Kedua, suatu negara memiliki tugas untuk mempromosikan kebebasan sesuai dengan kondisi otonomi. Dengan begitu setiap negara berhak memberikan hak dan wewenang kepada setiap masyarakatnya. Supaya masyarakat bisa memiliki kebebasan namun dalam artian bebas tidak sebebas-bebasnya. Karena meskipun begitu dalam suatu negara pasti memiliki undang-undang yang mengatur setiap hal yang dianggap melanggar norma atau aturan. Ketiga, setiap manusia pasti memiliki tujuan. Yang mana tujuan tersebut pasti akan berusaha dicapainya walaupun dengan berbagai cara. Salah satunya pasti ada yang melanggar otonomi rakyat, namun hal tersebut dapat dibenarkan jika hal itu bertujuan untuk melindungi otonomi dari orang-orang tertentu. ${ }^{10}$

Lebih lanjut, terkait keanekaragaman kultural Raz menjelaskan secara eksplisit. Dalam The Morality of Freedom ia menganggap bahwa masyarakat barat telah bersifat

${ }^{9}$ Ibid., 131

${ }^{10}$ Joseph Raz, The Morality of Freedom, (New York: Oxford University Press, 1986), 425. 
liberal dan mempertanyakan bagaimana masyarakat tersebut memperlakukan kelompok nonliberal yang disebut sebagai orang pinggiran. Dalam pandangannya, masyarakat barat merupakan penganut paham liberal. Walaupun demikian mereka juga menyadari akan adanya multikulturalisme. Masyarakat barat sebagai pusat dalam perkembangan dan sebagai kelompok superior jika dibandingkan dengan kelompok non liberal. Maka daripada itu, pertanyaannya bukan bagaimana sebuah masyarakat liberal harus memperlakukan kelompok minoritas non-liberal pinggiran, namun bagaimana masyarakat tersebut dapat sungguh-sungguh multikultur dan menyediakan ruang-ruang yang cukup bagi mereka tanpa menggerogoti integritas sendiri. Raz berpendapat bahwa manusia melekat secara sosial dan menganggap bahwa masyrakat memiliki kebudayaan tunggal. Ia menjelaskan kebudayaan memiliki dua fungsi vital. Pertama, kebudayaan menysusn dunia moral dan membangkitkan kesadaran para anggotanya. Kedua, kebudayaan sebgai penegas dalam pengakuan identitas diri. Berbagai macam kebudayaan yang pada dasarnya bersumber dari fungsi tersebut antara masyarakat liberal dan non liberal harus menaruh rasa hormat dan dukungan yang setara. Menurutnya, setiap manusia secara kultural terlekat dan tergantung pada kebudayaan mereka demi kebebasan, identitas dan kesejahteraan bersama. ${ }^{11}$

Masyarakat Barat yang mengambil budaya anonimitas, tetapi itu semua tidak cukup untuk mengatasi masalah multikulturalisme yang mulai muncul di banyak negara sebagai produk dekonolisasi. Budaya anonimitas bisa menyerap masing-masing migran, dan menindas mereka. Dengan budaya tersebut tidaklah bisa mengatasi kondisi masyarakat yang seperti itu. Mempercepat keterasingan dari masyarakat dan lembagalembaga, yang menyebabkan munculnya masyarakat kelas bawah berkembang. Oleh karena itu, Joseph Raz mengembangkan respon liberalnya untuk multikulturalisme dalam bentuk sikap dan kebijakan yang disebut sebagai toleransi. Dengan membiarkan minoritas berperilaku seperti yang mereka inginkan tanpa diskriminasi, selama mereka tidak menganggu budaya mayoritas, dan dengan kemampuan anggota mayoritas untuk menikmati gaya hidup mereka. ${ }^{12}$

${ }^{11}$ Ibid, 131.

${ }^{12}$ Joseph Raz, Multikulturalisme: A Liberal Perspektive. Pdf, 172. 
Terdapat dua jenis argumen untuk mendukung sebuah toleransi; pertama, alasan prinsip untuk membatasi penggunaan paksaan. Dalam prinsip ini, kelompok budaya minoritas yang tidak merugikan kelompok mayoritas tidak dapat diskriminalisasi. Kedua, membenarkan toleransi, demi perdamaian publik, ketenangan masyarakat, dan legitimasi sistem pemerintahan, karena semuanya dapat terancam oleh kebencian dan permusuhan dari kelompok minoritas yang tidak diinzinnkan dalam kegiatan budaya mereka. Sementara mendukung hak-hak non-diskriminasi, Multikulturalisme menekankan pentingnya aksi politik dari dua penilaian evaluatif. Pertama, keyakinan bahwa kebebasan individu dan kemakmuran tergantung pada keanggotaan penuh. Multikukturalisme sebagai sebuah pendekatan evaluatif pada keyakinan saling ketergantungan antara kesejahteraan dan kemakmuran individu yang berada pada kelompok budaya. Kedua, Multikulturalisme muncul dari keyakinan nilai pluralisme, dan validitas nilai-nilai yang diwujudkan dalam praktek budaya yang beragam dan banyak nilai-nilai yang tidak sesuai dengan masyarakat yang berbeda. ${ }^{13}$

Dapat dilihat bahwasannya kebebasan yang dimaksud oleh Raz adalah kebebasan yang terlepas dari dikotomi antara masyarakat liberal dan non liberal. Karena berdasarkan kajian yang disampaikan raz, terdapat kesenjangan yang cukup signifikan. Namun, Raz berusaha untuk membuka jalan tengah dalam upaya mendamaikan antar keduanya. Sebelumnya dijelaskan bahwa masyarakat barat modern bersifat liberal, akan tetapi tetap mengakui adanya multikulturalisme yang tentunya ada perbedaan-perbedaan yang mewarnainya. Sedangkan masyarakat non liberal dapat dikatakan cenderung eksklusif dan terbatas. Raz berusaha menghadirkan argumen bahwa jika paham liberal tidak hanya mewakili karakter individualistis semata. Melainkan ia memberikan pengertian untuk menjunjung tinggi perbedaan atau multikultural yang ada. Hal tersebut lebih spesifik terkait Ras dan agama tentang diskriminasi.Diskriminasi atas dasar agama, kebangsaan atau ras mempengaruhi korbannya dengan cara yang lebih mendasar. Oleh karenanya, anggapan tersebut harus dihapus dan ditiadakan agar tercapai kesejahteraan manusia dan terbentuk pemahaman masyarakat multikultur. ${ }^{14}$

${ }^{13}$ Ibid, 173-174.

${ }^{14}$ Joseph Raz, The Morality of Freedom, (Great Britain: Claredon Press, 1986), 254. 
Kesenjangan antara hubungan masyarakat barat liberal dengan non liberal membuat Raz perlu memberi jembatan antara keduanya. Pemahaman liberal adalah sebuah pengakuan akan adanya multikulturalisme dalam masyarakat. Liberal bukanlah semata-mata pengakuan budaya individual tertentu, melainkan seluruh, dan bersifat memahami akan perbedaan. Seorang atau kelompok liberal berbeda dengan non liberal yang cenderung ekslusif. Dia berusaha menjunjung tinggi pentingnya multikulturalisme. Dalam pewujudannya, perlu disadari bahwa kebebasan menjadi poin penting. ${ }^{15}$

Kebebasan dan kesetaraan adalah prinsip etis yang harus dibangun dalam masyarakat multikulturalistik pengakuan terhadap martabat manusia tidak dapat dilepaskan dari pengakuan terhadap kebebasan dan kesetaraan. Kebebasan diandaikan dalam pengembangan dan pengekspresian diri sebagai identitas, sementara kesetaraan diandaikan dalam menata kehidupan bersama yang harmonis. ${ }^{16}$

Kebebasan bisa bersifat negative, bisa juga positif. Kebebasan negative adalah kebebasan pada manusia yang menuntut tidak adanya campur tangan orang lain. Artinya, seseorang dapat bebas ketika orang lain tidak ikut campur tangan terhadap tindakan dan keputusannya. Misalnya, dalam kehidupan berbangsa dan bernegara seseorang dapat memilih agama yang ingin dia anut. Hal ini merupakan kebebasan negative, dikarenakan pemerintah tidak memiliki hak dalam mencampurinya. Tetapi, ketika saya ingin menjalankan kegiatan agama saya, saya menuntut adanya campur tangan pemerintah agar dapat mewujudkannya tanpa direcoki oleh pihak lain (kebebasan positif). ${ }^{17}$

Prinsip kebebasan disampaikan setidaknya dalam 3 poin yakni, pertama, toleransi pada kebudayaan, kedua, menerima rasa hormat dan dukungan yang setara, dan ketiga, Negara adalah kepemilikan yang universal, dan perlunya kesempatan partisipasi yang cukup.

Toleransi harus diberikan kepada setiap kebudayaan, dan segala macam perbedaan, termasuk, agama, etnis, ras, suku, warna kulit, dan bahasa, yang ada di dalam sebuah Negara. Suatu kebudayaan mungkin mempromosikan kesejahteraan manusia namun tidak otonom, sebagaimana terjadi dengan banyak kasus masyarakat hierarkis dan

\footnotetext{
15 Joseph Raz, The Morality of Freedom, (Great Britain: Claredon Press; 1986), 254.

${ }^{16}$ Benyamin Molan, Multikulturalisme Cerdas Membangun Hidup Bersama yang Stabil dan Dinamis, (Jakarta: Indeks, 2015), 50.

17 Ibid, 38-39.
} 
tradisional. Atau kebudayaan mungkin mendorong suatu pandangan ekstrem atas otonomi yang tidak sanggup menyediakan perasaan ekstrem atas otonomi yang tidak sanggup menyediakan perasaan sebagai komunitas, fokus bagi identifikasi kolektif, dunia yang kaya memiliki hubungan personal yang mendalam dan bahkan ikatan antargenerasi. Inilah yang oleh beberapa orang diduga terjadi pada masyarakat liberal. Raz sadar atas ketegangan antara kedua dimensi kebudayaan tersebut, dan menganggap bahwa tidak ada satu kebudayaan pun yang boleh dinilai hanya oleh kebudayaan lainnya. Sehingga mereka berhak diberikan toleransi, sekalipun yang diberikan toleransi adalah kebudayaan yang represif. Karena suatu kebudayaan berada di antara kebudayaan-kebudayaan lain, kebudayaan tersebut juga harus bersedia bertoleransi dan hidup secara damai. ${ }^{18}$

\section{Hasil Penelitian}

\section{Sejarah}

Gereja Yesus Kristus dari Orang-orang Suci Zaman Akhir adalah salah satu gereja yang hidup dan berkembang di Indonesia. Dia adalah gereja yang lahir di Amerika, yang kemudian dibawa oleh para missionaries untuk disebarkan ajarannya. Situasi keagamaan di Amerika pada awal abad ke-19 mempersiapkan iklim yang kondusif bagi perkembangan gerakan-gerakan keagamaan baru. Gereja-gereja utama (antara lain Episcopal, Metodis, Baptis, Presbyterian, dan Kongregasionalis) secara umum lemah, sedangkan kemajemukan dan kebebasan beragama yang dijamin undang-undang merangsang pengungkapan rasa keagamaan yang bersifat individual dan independen. Demokratisasi kebudayaan Amerika, kebangunan besar kedua dan kebangunan rohani yang merupakan lanjutannya, ikut merangsang dan meningkatkan individualism religious ini. Ditambah dengan berbagai pertikaian dan kekhawatiran disepanjang tahun 1830-an, maka lahirlah gerakan-gerakan baru, terutama dari gereja-gereja Protestan. Salah satu diantaranya adalah Gereja Yesus Kristus dari Orang-orang Suci Zaman Akhir (OSZA) atau The Church of Jesus Christ of Latter Day Saints. Orang-orang di luar gereja ini mengenalnya dengan Gereja Mormon. ${ }^{19}$

\footnotetext{
${ }^{18}$ Bhikhu Parekh, Rethinking Multicuturalism, (Yogyakarta: Kansius; 2008), 134.

19 Nurdewi Mayangsari, Konsep Kenabian dalam Doktrin Kristen Mormon Skripsi.pdf, diakses melalui http://repository.uinjkt.ac.id/dspace/bitstream/123456789/36629/2/NURDEWI\%20MAYANG\%20SARI-FU.pdf.

Pada 4 Juli 2018, 3,4
} 
Gereja yang memiliki nama resmi The Church of Jesus Christ of the Latter-Day Saints (Gereja Yesus Kristus dari Orang-orang Suci Zaman Akhir) ini adalah sebuah aliran gereja yang didirikan oleh seorang yang dianggap nabi dalam aliran tersebut yang bernama Joseph Smith, Jr. (1805-1844). ${ }^{20}$ Wahyu pertama Smith didapatkan ketika ia berusia $14^{\text {th }}$. Pada usia tersebut, dia ingin mengetahui mana geraja yang benar yang akan ia ikuti. Lalu, ia bertanya kepada Allah dalam doa yang sungguh-sungguh, dan di kabulkannya doa tersebut. Ia mendapat penglihatan mengenai dua tokoh sorgawi yang muncul di hadapannya dan menyatakan diri sebagai Allah Bapa dan Putera-Nya Yesus Kristus, dan seorang dari mereka berkata "Inilah anak yang Kukasihi, dengarkanlah dia" dan Mereka menasihatkan Joseph untuk tidak mengikuti salah satu ajaran gereja dan agama yang ada di sekitarnya karena dinilai semua perhimpunan agama tersebut mempercayai ajaran yang keliru. ${ }^{21}$

Jemaat gereja Mormon orang-orang suci zaman akhir percaya bahwa dia dipanggil oleh Allah untuk menjadi nabi di zaman modern, seperti Musa dan Abraham di zaman Al Kitab. Joseph Smith melihat Allah dan Yesus Kristus dalam suatu penglihatan setelah berdoa untuk mengetahui gereja mana yang harus dia bergabung. Mereka memanggilnya untuk memulihkan Gereja yang diorganisasi oleh Kristus ketika Dia berada di bumi, dengan organisasi dan wewenang imamat yang tepat yang telah hilang tidak lama setelah kematian Juruselamat. Dan dimana dari awalnya enam anggota pada tahun 1830, Gereja Yesus Kristus telah berkembang dengan keanggotaan hampir 14 juta di enam benua. Setelah kematian Joseph Smith, suksesi berkesinambungan dari para nabi yang telah memimpin Gereja, selalu berusaha untuk membawa para anggota pada pemahaman yang lebih baik dan kasih yang lebih besar bagi Injil Yesus Kristus. ${ }^{22}$

Setalah mengalami penampakan dengan hadirnya Moroni, putra Mormon yang telah dialamai oleh Smith. Moroni memberitahu Joseph tentang sejumlah lempengan emas yang ada di bukit kecil dekat Palmyra dan mengandung tulisan yang sangat berharga. Ia pun dilarang memindahkan lempengan itu dari tempat persembunyian hingga saat yang yang akan ditetapkan oleh Tuhan. Kemudian ia mendapat penglihatan yang berisi

20 Kenneth A. Corbett, Ajaran dan Perjanjian serta Ajaran Gereja.pdf, dikases melalui file:///C:/Users/HP/Downloads/35685_ind.pdf. Pada 23 Juni 2018.

${ }^{21}$ OSZA, Gereja Yesus Kristus dari Orang-Orang Suci Zaman Akhir, (Jakarta: Pusaka Kita, 1998), 1-4.

22 Diakses pada situs resmi gereja Mormon, https://www.mormon.org/ind/tentang-kami. Pada 5 juli 2018. 
petunjuk dan izin untuk mengambil dan menerjemahkan isi lempengan emas itu. Pada awal 1830 naskah itu terwujud secara mujizat dan menjadi sebuah buku dan diberi nama Kitab Mormon dimana Kitab itu merupakan kitab suci baru yang diterjemahkan dari lempengan emas, yang dijadikan kitab ke-2 bagi para jemaat gereja ini. ${ }^{23}$

Kemudian, missionarisasi semakin marak dilaksanakan di berbagai Negara, di belahan dunia, tak terkecuali Indonesia. Ada banyak sekali kota yang dikunjungi, seperti Jakarta, Bandung, Jogjakarta, Malang, Surabaya, dan masih banyak lainnya. Di Surabaya sendiri, terdapat dua buah gereja yang masing-masing terletak di daerah Putat Indah dan di Jl. Upa Jiwa Ngagel. Keberadaan gereja-gereja ini tidak terlepas dari dua orang missionaries berkebangsaan Amerika, yakni Elder Meldon K. Larson dan Elder Robert Warren M. Harper (1973). ${ }^{24}$ Kedua orang missioner yang ingin memperluas dakwahnya ini membawa izin berupa selembar kertas dari Departemen Agama RI yang dikeluarkan di Jakarta pada tanggal 18 April 1970 dengan No. Dd/P/VIII/25/294/70. Setelah cukup lama melakukan missionarisasi dan memiliki banyak jemaat, mereka mengajukan untuk pendirian rumah ibadah, guna mempermudah koordinir dan pelaksanaan ibadah. Pengajuan tersebut bukanlah perkara yang mudah, hingga pada tanggal 20 November 1989 bangunan gedung tersebut telah rampung secara keseluruhan dalam pembangunannya dan diresmikan pada hari itu oleh Presiden Misi, yakni Piet Hien Tandiman yang juga dihadiri oleh banyak anggota gereja, tokoh masyarakat sekitar Putat Indah, para kontraktor,dan pejabat wali kotamadya Surabaya. Kemudian disusul, menjelang pertengahan tahun 2002, dibangun satu lagi gedung Gereja Yesus Kristus dari Orang-orang Suci Zaman Akhir untuk cabang Surabaya Timur yang sama besar dan megahnya di Jl. Upa Jiwa. Diresmikan pada tanggal 19 Desember 2002 yang dihadiri oleh pejabat walikota madya Surabaya, tokoh masyarakat setempat, para pejabat dan anggota gereja dalam peresmian gereja tersebut. ${ }^{25}$

\section{Ajaran}

\footnotetext{
${ }^{23}$ Ibid.

${ }^{24}$ Hadi Sutanto, Wawancara, Surabaya,14 Juni 2018.

${ }^{25}$ Ibid.
} 
Dalam Kristen mormon ini memiliki 2 kitab, yaitu al kitab dan kitab mormon. Kitab mormon berisi tulisan-tulisan nabi kuno. ${ }^{26}$ Kitab mormon juga memberikan kesaksian tentang yesus kristus, artinya Kristen mormon tidak bertentangan dengan al kitab. Dalam Alkitab dijelaskan tentang keilahian yesus kristus dan telah memengaruhi dan mendukung jutaan pengikutnya. Alkitab adalah suatu kumpulan tulisan suci yang berisi wahyu Allah dan catatan hubungannya dengan anak-anaknya di tanah suci. ${ }^{27}$ Kitab Mormon ditulis di Amerika kuno sedangkan Alkitab di tulis di Yerussalem. Isi dari kitab Mormon tidak hanya kata penyemangan tetapi juga cerita nabi nabi kuno. ${ }^{28}$

Kristen Mormon mempercayai Alkitab sebagai "firman Allah sejauh kitab itu diterjemahkan dengan benar." Mereka percaya bahwa kebanyakan terjemahan Alkitab mengandung banyak kesalahan atau dengan sengaja diubah dari teks aslinya. Kitab Mormon serta Ajaran dan Perjanjian sama-sama diterbitkan sebagai wahyu dari Allah Israel untuk mengumpulkan dan mempersiapkan umatNya bagi kedatangan kedua Tuhannya. ${ }^{29}$ Dalam ajarannya, kitab Mormon serta ajaran dan perjanjian saling memberikan kesaksian. Yang dimaksud dengan memberikan kesaksian yakni "kitab Mormon bersaksi tentang kitab-kitab tulisan suci modern. Kitab Mormon merujuk kitabkitab tersebut sebagai "kitab-kitab lain" dan "catatan terakhir" yang "menegakkan kebenaran" tentang Alkitab dan mengungkapkan "hal-hal yang jelas dan berharga yang telah dihilangkan" dari Alkitab (1 Nefi 13 :39-40). ${ }^{30}$ Ajaran dan perjanjian sungguh merupakan saksi dan bukti luar yang terbesar yang kita miliki dari Tuhan bahwa Kitab Mormon adalah benar. Begitu pun dengan kata-kata dan cara yang mereka gunakan dalam kitab Momon yang berasal dari Tuhan hendaknya menjadi sumber pemahaman dan digunakan untuk mengajarkan asas-asas injil.

Ajaran dan perjanjian adalah mata rantai yang tak terputuskan antara kitab Mormon serta pekerjaan pemulihan yang bekelanjutan melalui Nabi Joseph Smith dan para penerusnya. Dalam ajaran dan perjanjian kita belajar mengenai pekerjaan bait suci,

\footnotetext{
${ }^{26}$ Christine Prayitno Silalahi, Wawancara, Surabaya, 1 Juli 2018

27 Gereja Yesus Kristus dari Orang orang Suci Zaman Akhir, Alkitab, diakses melalui https://www.mormon.org/ind.psd. Pada 6 Juli 2018.

${ }^{28}$ Christine Prayitno Silalahi, Wawancara, Surabaya, 1 Juli 2018.

${ }^{29}$ Ezra Taft Benson, Kitab Mormon Serta Ajaran dan Perjanjian, diakses melalui https://www.Ids.org. Pada 5 Juli 2018.

${ }^{30}$ Kitab 1 Nefi $13: 39-40$.
} 
keluarga kekal, tingkat-tingkat kemuliaan, organisasi Gereja, serta banyak kebenaran lainnya mengenai Pemulihan. ${ }^{31}$

Keunikan dalam Kristen Mormon adalah kepercayaan mereka terhadap nabi yang masih hidup hingga saat ini, joseph smith merupakan nabi mereka era modern. Menurutnya, nabi adalah orang yang dipanggil allah untuk menjadi wakilnya di bumi yang merupakan saksi khusus kistus. ${ }^{32}$ Dalam perjanjian baru bahwa setelah Yesus menetapkan 12 rasulnya bahwa kumpulan tersebut dimaksudkan untuk berlanjut dari peristiwa yang terjadi pada kisah para rasul 1 ketika 11 rasul dibawah arahan Petrus, memilih Matias sebagai rasul baru untuk menggantikan Yudas. Setelah kematian nabi Joseph Smith di chartange illiniois brigham young memimpin gereja ke lembah salt lake dan membimbing pertumbuhan dan perluasannya di seluruh daerah barat. Setelah kematiannya, rasul John Taylor menjadi presiden ke tiga gereja. ${ }^{33}$

Dalam Kristen Mormon memiliki banyak ajarannya yang hampir sama dengan Kristen Protestan. oleh karena itu, di Indonesia agama kristen Mormon dikelompokkan dalam kubu Kristen protestan. ${ }^{34}$ Para penganut agama Kristen mormon percaya bahwa ada empat sumber firman yang diinspirasikan Allah. pertama Alkitab, kitab Mormon, doktrin dan perjanjian, mutiara yang berharga. Pokok-pokok ajaran gereja Yesus Kristus dari Orang-orang Suci Zaman Akhir ini terdapat pada dokumen pasal-pasal iman yang dimuat pada bagian terakhir kitab mutiara yang sangat berharga (kumpulan wahyu, terjemahan, dan tulisan-tulisan Yoseph Smith). Pasal-pasal kepercayaan tersebut adalah: a. Kami percaya kepada Allah, Bapa yang kekal, serta putraNya, yesus kristus dan roh kudus, b. Kami percaya bahwa orang akan dihukum untuk dosanya sendiri dan bukan untuk pelanggaran Adam, c. Kami percaya bahwa melalui penebusan kristus, seluruh umat manusia dapat diselamatkan dengan jalan mematuhi hukum-hukum serta tatacara

\footnotetext{
${ }^{31}$ Ezra Taft Benson, Kitab Mormon Serta Ajaran dan Perjanjian, diakses melalui https://www.Ids.org. Pada 5 Juli 2018.

32 Nurdewi Mayangsari, Konsep Kenabian dalam Doktrin Kristen Mormon.pdf, diakses melalui https:///.google.co.id/url?sa=t\&source=web\&rct=j\&url=http://repository.uinjkt.ac.id/dspace/bitstream/123456789/36 629/2/nurdewi\%2520mayang\%2520sari-

fu.pdf\&ved=2ahukewi4tbqg_yvcahxcbn0khrzscoeqfjafegqiaxab\&usg=aovvaw3hmokfcasnyc34mvem-4sq. Pada 6 Juli 2018.

33 Gereja Yesus Kristus dari Orang Orang Suci Zaman Akhir, Nabi, diakses melalui https://www.mormon.org/ind.psd. Pada 7 Juli 2018.

${ }^{34}$ Elder Hurt, Wawancara, Surabaya 1 Juli 2018.
} 
injil, d. Kami percaya bahwa seseorang harus dipanggil oleh Allah, melalui nubuat, serta dengan penumpangan tangan oleh mereka yang mempunyai wewenang untuk memberitakan injil serta melaksanakan tatacara-tatacara daripadanya. ${ }^{35}$

Orang yang belum mengenal Kristen Mormon banyak yang mengatakan bahwa ajaran Kristen Mormon merupakan ajaran yang sesat. Banyak opini dimasyarakat yang mengatakan bahwa ritual Kristen mormon adalah ritual yang aneh seperti mengiris iris tangan dan meminum darahnya. Padahal itu sama sekali tidak pernah dilakukan. Oleh karena itu mereka berharap untuk tidak membuat opini sendiri sebelum mengenal apa itu Kristen Mormon. ${ }^{36}$

Dalam ritual peribadatannya Gereja Yesus Kristus Dari orang-Orang Suci Zaman Akhir ini melakukan kegiatan selama tiga jam di dalam gereja yaitu mulai pukul 9 pagi sampai pukul 12 siang. Selama tiga jam itu mereka melakukan ritual yaitu satu jam pertama adalah pertemuan sakramen kemudian jam kedua adalah sekolah minggu yang isinya doktrin dalam ajaran Kristen mormon, kemudian di jam terakhir itu pengaplikasian dari dokrin ke dalam kehidupan sehari-hari. ${ }^{37}$

Menurut gereja Mormon, Allah adalah sempurna, maha bijak, dan maha kuasa, penguasa alam semesta, dia juga penuh belas kasihan, baik hati, dan adil. Dia adalah bapak di surga. Bersama bukti ciptaanya bapa surgawi telah memberi banyak cara untuk mengetahui bahwa ia hidup. ${ }^{38}$ Menurut mereka Allah menggunakan kekuatan kata-kata dalam Kitab Mormon sebagai alat untuk mengubah kehidupan orang-orang39: "Maka karena pengkhotbahan firman mempunyai kecenderungan yang besar untuk memimpin orang-oang melakukan apa yang adil-ya, firman itu telah mempunyai pengaruh yang lebih kuat terhadap jiwa orang daripada pedang atau apapun yang telah terjadi kepada

${ }^{35}$ Gereja Yesus Kristus dari Orang-Orang Suci Zaman Akhir, diakses melalui, https://id.m.wikipedia.org. Pada 5 Juli 2018.

${ }^{36}$ Christine Prayitno Silalahi, Wawancara, Surabaya, 1 Juli 2018

${ }^{37}$ Elder Hurt, Wawancara, Surabaya 1 Juli 2018

38 Gereja Yesus Kristus dari Orang Orang Suci Zaman Akhir, Allah, diakses melalui https://www.mormon.org/ind.psd Pada 7 Juli 2018.

${ }^{39}$ Ezra Taft Benson, Kitab Mormon Serta Ajaran dan Perjanjian, diakses melalui, https://www.Ids.org. Pada 5 Juli 2018. 
mereka-karena itu Alma berpendapat bahwa perlulah mereka mencoba kekuatan firman Allah" (Alma 31:5). ${ }^{40}$

\section{Hubungan Gereja dengan Negara}

Hubungan Gereja Yesus Kristus dari Orang-orang Suci Akhir Zaman (Mormon) dengan negara atau pemerintah dapat dikatakan sangat baik. Negara selaku pemangku kebijakan dan pemangku kewajiban hak-hak dari warga negara termasuk didalamnya jemaat gereja ini memberikan hak-haknya sebagaimana mestinya. Tidak ada bentuk diskriminasi atau pelanggaran hak yang dilakukan oleh Negara terhadap gereja ini. Meskipun gereja ini dapat disebut gereja minoritas diantara gereja yang lain di negara ini, namun aktivitas atau kegiatan yang mereka laksanakan berjalan dengan aman, tentram dan damai. Disisi lain, Negara juga berperan aktif dalam pemenuhan hak bagi gereja ini. Dapat diketahui bahwa mulai dari adanya pemeberian izin berdirinya gereja sampai adanya bantuan subsidi untuk keperluan rumah ibadah yang diterima dengan baik. Negara tidak melakukan tebang pilih dalam pemberian izin dan subsidinya. Sebagai seorang minoritas ditengah-tengah minoritas tidak membuat gereja ini terhapus zaman. Izin pendirian rumah ibadah pada era berdirinya gereja Mormon memang belum serumit sekarang, Namun, kebebasan memang nyata masih melekat hingga sekarang. Buktinya bahwa gereja ini masih eksis dan megah berdiri. ${ }^{41}$

Subsidi yang diberikan Negara bagi gereja ini berupa dua macam, yang pertama adalah subsidi wajib. Subsidi ini adalah subsidi gedung, atau public place, yang biasanya berupa aliran air bersih, dan listrik. Kemudian, yang kedua adalah subsidi berupa pengadaan barang atau keperluan-keperluan peribadatan gereja, dan perbaikan gedung. Subsidi ini, perlu dilakukan pengajuan terlebih dahulu kepada pihak Negara sebagai salah satu prosedur yang memang ditetapkan Negara bagi siapapun (kelompok agama manapun). Diluar kedua subsidi yang diberikan Negara, sebenarnya gereja secara legal juga mendapatkan subsidi dari luar Negara, atau dapat dikatakan pusat dari gereja

${ }^{40}$ Kitab Mormon Alma 31:5.

${ }^{41}$ Angga Arie, Wawancara, Surabaya, 25 Juni 2018. 
bermuara (Amerika). Dan juga disamping itu, ada pula subsidi yang diberikan oleh jemaat. $^{42}$

Terkait dengan ajarannya, Negara sebenarnya memang telah melakukan intervensi, sebagaimana yang telah diketahui, Indonesia adalah Negara yang menetapkan masyarakatnya untuk beragama atau berkeyakinan kepada dzat yang Esa (tunggal). Akan tetapi, hal ini sejatinya tidak begitu munyusahkan atau memberatkan jemaat Gereja Mormon. Karena, memang apa yang disyaratkan oleh Negara adalah memang sebagaimana yang dipercaya, dikerjakan, dan diyakini oleh para jemaat. Intervensi tersebut berupa pengelompokkan aliran. Sejatinya, pihak gereja sendiri menyatakan dirinya sebagai gereja yang independent. Artinya, mereka tidak memihak Katolik, maupun Protestan, karena memang mereka bukan bagian dari keduanya. Mereka memiliki ciri dan karakteristiknya sendiri. Namun, kenyataan berkata bahwa bila ingin berada dan berkembang di Indonesia, maka sudah barang tentu harus mematuhi peraturan yang berlaku. Sehingga, gereja ini oleh pemerintah dikelompokkan kedalam kubu Protestan. ${ }^{43}$

Selain itu, untuk perlindungan ketika beribadah, khususnya ketika ada pelaksanaan hari-hari suci besar keagamaan, seperti Hari Raya dan sebagainya mereka juga kerap memperoleh perlindungan ketat dan khusus dari aparat kepolisian, untuk mengamankan, dan menjaga kesakralan dan kekhusyukan peribadatan, menghalau dan meminimalisir gangguan-gangguan yang akan atau mungkin terjadi dari luar gereja. Para jemaat bebas melakukan ritual mereka selama itu tidak mengganggu ketertiban umum, seperti merusak fasilitas umum, blockade jalan hingga berhari-hari dan tanpa melakukan perizina dan lain-lain. Dalam peribadatannya, mereka diperbolehkan menggunakan nyanyian dan pengeras suara selama hal itu memang diperlukan. Intinya tidak ada bentuk pengecualian yang benar-benar mengurangi hak-hak mereka selaku warga negara. ${ }^{44}$

\section{Hubungan Gereja dengan Masyarakat Sekitar}

\footnotetext{
${ }^{42}$ Ibid.

${ }^{43}$ Christin Prayitno Silalahi, Wawancara, Surabaya, 25 Juni 2018.

${ }^{44}$ Ibid.
} 
Hubungan antara gereja dengan masyarakat sekitar sejauh ini baik-baik saja. Gereja, sama sekali tidak pernah mendapatkan perlakuan kasar, seperti demo, pelemparan batu, bom, atau bentuk perusakan-perusakan lainnya. Hal ini dapat diselaraskan dengan salah satu metode missionarisasi gereja yakni "bersosialisasi antarumat". Dari metode ini, membawa mereka jadi lebih mudah dalam hal berinteraksi dengan warga sekitar. Sosialisasi mereka sangatlah terstruktur dan dapat dikelompokkan dalam beberapa tingkatan, yakni dari yang terkecil adalah tingkat desa/kecamatan, kota, provinsi, Negara, dan Internasional. Untuk sosialisasi tingkat desa/kecamatan sangat beragam bentuknya, diantaranya kerja bakti bersama, membantu pembangunan balai RW, dan beberapa public place lain, memperbaiki rumah warga yang membutuhkan renovasi, berbagi berkat berupa sembako, kepada janda-janda tua yang membutuhkan yang bekerjasama dengan pihak kelurahan dan karang taruna, mengadakan bimbingan belajar bahasa asing setiap 2x seminggu, khususnya bahasa Inggris secara gratis, memberikan bimbingan permainan basket, senam bersama dalam segala usia, dan baru-baru ini mereka bekerjasama dengan kominitas IPCI (Iyou Present Community Indonesia) untuk berbagi takjil bersama kepada muslim yang tengah melaksanakan ibadah puasa, dan masih banyak lainnya. ${ }^{45}$

Sementara bila dalam kota, biasanya masih merangkap dengan setingkat kecamatan, hal ini dikarenakan dalam setiap kota, terkadang hanya didapati 1 gereja saja, sementara bila provinsi, kegiatannya biasanya masih berlingkup pada humanity khususnya pendidikan dan kelaparan. Mereka juga cukup tanggap dalam isu-isu nasional maupun internasional seperti baru-baru ini mereka melakukan sosialisasi dan pemberian bantuan di Afrika, terkait kelaparan dan gizi buruk. Dari sekian banyak kegiatan yang coba dilakukan, gereja mendapat respon positif dari masyarakat, meskipun terkadang perlu adanya penjelasan singkat terkait maksud dan tujuan bantuan dan sosialisasi diberikan. Meskipun mereka jarang mendapati penolakan, namun bukan berarti tidak ada. Penolakan tersebut biasanya berupa kata-kata. Akan tetapi itu tidak menjadi masalah yang amat serius dari bagi pihak gereja. Mereka menyadari hal tersebut, dan mencoba memberikan penjelasan, namun bila masih tidak dapat, maka mereka juga tidak melakukan pemaksaan. Bagi mereka, sudah hal yang wajar jika penolakan dilontarkan

${ }^{45}$ Christian Prayitno Silahi, Wawancara, Minggu, 25 Juni 2018. 
secara individual ketika dilakukan sosialisasi. Hal ini bisa saja terjadi dikarenakan mereka tidak mengenal ajaran yang sesungguhnya, terlalu banyak mengkonsumsi berita bohong, dan tidak pernah mencoba melakukan interfaith dialogue. Selama hal tersebut tidak menimbulkan opini masyarakat, dan menjadi diskriminasi secara fisik pihak gereja tidak pernah mempermasalahkan hal tersebut. ${ }^{46}$

Setiap kegiatan sosial mereka, dana yang diperlukan sama sekali tidak menggunakan dana Negara, atau subsidi. Semuanya dilakukan dengan menggunakan dana pribadi jemaat. Gereja Mormon ini adalah salah satu yang sangat menekankan pentingnya berbagi dengan sesama (humanity), meskipun kita tahu, semua agama mengajarkan humanity. ${ }^{47}$

\section{E. Kesimpulan}

Selaras dengan teori kebebasan yang coba disampaikan Joseph Raz, dimana kebebasan beragama sesungguhnya adalah kombinasi dari dua hal, yakni kebebasan positive dan negative. Kebebasan negative, yakni kebebasan pada manusia yang menuntut tidak adanya campur tangan orang lain. Artinya, seseorang dapat bebas ketika orang lain tidak ikut campur tangan terhadap tindakan dan keputusannya. Misalnya, dalam kehidupan berbangsa dan bernegara seseorang dapat memilih agama yang ingin dia anut. Hal ini merupakan kebebasan negative, dikarenakan pemerintah tidak memiliki hak dalam mencampurinya. Tetapi, ketika saya ingin menjalankan kegiatan agama saya, saya menuntut adanya campur tangan pemerintah agar dapat mewujudkannya tanpa direcoki oleh pihak lain (kebebasan positif). ${ }^{48}$

Dalam hal ini, Negara harusnya memberikan kebebasan secara utuh dalam hal aliran, ajaran, dan pemikiran kelompok keagamaan tanpa adanya intervensi dalam bentuk apapun. Negara harus mampu memegang komitmennya ketika dia telah memutuskan seorang missionaries masuk dan diberikan izin berdakwah, maka sudah sepantasnya Negara tidak kembali mengintervensi dakwahnya.

\footnotetext{
${ }^{46}$ Elder Rushadi, Wawancara, Minggu, 25 Juni 2018

${ }^{47}$ Angga Arie P, Wawancara, Minggu, 25 Juni 2018

${ }^{48}$ Benyamin Molan, Multikulturalisme Cerdas Membangun Hidup Bersama yang Stabil dan Dinamis, (Jakarta: Indeks, 2015), 38-39.
} 
Sementara dalam hal pemenuhan kebebasan positive, yakni berupa perlindungan ketika beribadah, pemenuhan subsidi, pengadaan alat peribadatan, sampai kekhusyukan, maka sudah seharusnya pemerintah memberikan kebebasan tersebut kepada setiap masyarakatnya yang beragama apapun itu. Tidak hanya berhenti sampai disitu, kebebasan dan perlindungan diluar rumah ibadah, atau sebagai seorang warga sipil yang beragama, keselamatannya juga masih menjadi tanggung jawab Negara secara utuh, seperti terhindarkan dari hate speech. Negara perlu mengadakan edukasi akan pentingnya pluralisme kepada masyarakat, dan menambah porsi interfaith dialogue di dalam masyarakat.

Masyarakat sendiri, juga perlu bersikap adil, dan mulai memandang perbedaan itu indah. Mereka juga harus belajar dan mulai mengerti bahaya dari hate speech yang dilontarkan secara sengaja kepada kelompok agama atau kepercayaan lain. Dalam kubu Kristen sendiri, masyarakat perlu mengakui "sesama Kristen" adalah juga sudah seharusnya ditanamkan, mengingat Kristen dalam gereja Mormon ini adalah minoritas ditengah-tengah minoritas. Sehingga, dapat telaksana kebebasan yang sesungguhnya, dan kedamaian.

\section{F. Daftar Pustaka}

Akhir, Gereja Yesus Kristus dari Orang orang Suci Zaman. 2018. Alkitab. Diakses melalui https://www.mormon.org/ind.psd.

Akhir, Gereja Yesus Kristus dari Orang Orang Suci Zaman. 2018. Allah. Diakses melalui https://www.mormon.org/ind.psd.

Akhir, Gereja Yesus Kristus dari Orang Orang Suci Zaman. 2018. Nabi. Diakses melalui https://www.mormon.org/ind.psd.

Arie, Angga. 2018. Wawancara, Surabaya.

Benson, Ezra Taft. 2018. Kitab Mormon Serta Ajaran dan Perjanjian. Diakses melalui https://www.Ids.org.

Corbett, Kenneth A. 2018. Ajaran dan Perjanjian serta Ajaran Gereja.pdf. Dikases melalui file:///C:/Users/HP/Downloads/35685_ind.pdf.

Hurt, Elder. 2018. Wawancara. Surabaya. 
Huda, M Thoriqul. "Potret Kerukunan Pemuda Lintas Agama Di Jawa Timur." In PROCEEDINGS: Annual Conference for Muslim Scholars, 929-36, 2018.

Kitab Mormon Alma 31:5.

Kitab 1 Nefi $13: 39-40$.

Molan, Benyamin. 2015. Multikulturalisme Cerdas Membangun Hidup Bersama yang Stabil dan Dinamis. Jakarta: Indeks.

Nasution, S. 2009. Metode Research, Jakarta: PT. Bumi Aksara.

Nurdewi Mayangsari. 2018. Konsep Kenabian dalam Doktrin Kristen Mormon Skripsi.pdf. Diakses melalui http://repository.uinjkt.ac.id/dspace/bitstream/123456789/36629/2/NURDEWI\%20 MAYANG\%20SARI-FU.pdf.

OSZA. 1998. Gereja Yesus Kristus dari Orang-Orang Suci Zaman Akhir. Jakarta: Pusaka Kita.

Parekh, Bhikhu. 2008. Rethinking Multicuturalism. Yogyakarta: Kansius.

Raz, Joseph. Multikulturalisme: A Liberal Perspektive. Pdf.

Raz, Joseph. 1986. The Morality of Freedom. New York: Oxford University Press.

Rushadi, Elder. 2018. Wawancara. Surabaya.

Silalahi, Christin Prayitno.2018. Wawancara. Surabaya.

Spraddly, James P. 2006. Etnografi, Yogyakarta: Tiara Wacana.

Sutanto, Hadi. 2018. Wawancara, Surabaya.

TN. 2018. Diakses pada situs resmi gereja Mormon, https://www.mormon.org/ind/tentang-kami.

TN. 2018. Gereja Yesus Kristus dari Orang-Orang Suci Zaman Akhir. Diakses melalui, https://id.m.wikipedia.org.

TN. 2018. Perjanjian. Diakses melalui, https://www.Ids.org. 